\title{
Morphoanatomy and Gonadosomatic Index (GSI) of Testis of Turkey (Melagris gallopavo) at Different Ages
}

\author{
Dian Masyitha ${ }^{1,2^{*}}$, Muslim $\mathrm{Akmal}^{2}$, Gholib Gholib ${ }^{3}$, and Sri Wahyuni ${ }^{4}$ \\ ${ }^{I}$ Graduate School of Mathematics and Applied Science, Universitas Syiah Kuala, Banda Aceh, Indonesia \\ ${ }^{2}$ Laboratory of Histology, Faculty of Veterinary Medicine, Universitas Syiah Kuala, Banda Aceh, Indonesia \\ ${ }^{3}$ Laboratory of Physiology, Faculty of Veterinary Medicine, Universitas Syiah Kuala, Banda Aceh, Indonesia \\ ${ }^{4}$ Laboratory of Anatomy, Faculty of Veterinary Medicine, Universitas Syiah Kuala, Banda Aceh, Indonesia \\ Corresponding author.Email: dian_m@mhs.unsyiah.ac.id
}

\begin{abstract}
Testis is a male reproductive organ that responsible for producing the spermatozoa and regulating the reproductive hormones. Study on morphoanatomy and gonadosomatic index (GSI) can provide overview on the development of male reproduction. The study was conducted to determine the testicular morphoanatomy and GSI of turkey (Meleagris gallopavo) at different ages. This study used 18 turkeys with three different age groups namely 8, 16, and 24 weeks. Each age group consisted of six turkeys. The results showed that the testes had a nut like shape and located in the abdominal cavity between a dorsal of intestine, caudal of lungs and ventral of kidneys. The color of testicles was pale white to beige white and some of them were black. The GSI of 8, 16, and 24-week turkeys were $0.96 \pm 0.32 \%, 1.32 \pm$ $0.42 \%$, and $9.53 \pm 8.26 \%$. The GSI increased in line with age, indicating the development of male reproduction organs the animals.
\end{abstract}

Keywords: Morphoanatomy, gonadosomatic index, turkey

\section{INTRODUCTION}

Turkey (Meleagris gallopavo) is a type of poultry that has a large body and attractive appearance, beautiful feather type and color, a unique sound. The the wingspan of this bird can reach 1.5-1.8 meters. A male turkeys are bigger than females. Recently in Indonesia, raising turkeys has become a promising business opportunity and is easy to do. For that we need to have an understanding in the selection of good quality and healthy brood stock and males.

In connection with the steps that will be taken in the effort to develop turkey, therefore, technical management in livestock raising is one aspect of reproduction that is important to study further because it greatly influences efforts to increase the productivity of livestock to be cultivated [1]. Efforts to increase livestock productivity can be done in two ways, namely increasing livestock population and increasing livestock genetics [2]. Improving the genetic quality of livestock in terms of reproductive aspects has a relationship between body weight, body size, age, and testicular characteristics [3].
Body size can give a picture of the exterior of a livestock [4], which can be used as a selection starter in livestock breeding and production [5]. The main reproductive organs of the male are the testes. In male poultry, the testes do not descend in the scrotum but remain in the body cavity [6], especially in the abdominal cavity at the front of the kidneys and the back of the lungs, and is lined with fibrous tissue [7]. Poultry testes are round beans-shape with a size varies according to age and body size [6]. Fitriyah et al. [8] added that a normal testicle anatomically has the appropriate weight, length and circumference. The weight of testes reflects the volume of seminiferous tubules, the main component of testes that produce sperm [9].

The development of the male reproductive organs can be viewed from the morphometrics of the testes. Testicular morphometrics are required to evaluate quantitative changes in the testicular size and spermatogenic function [10]. Testicular size highly correlates with livestock genetic factors [11] so that the anatomy of the testes can be used as an indicator of livestock reproductive activity [9]. 


\section{MATERIALS AND METHODS}

\subsection{Tools and Materials}

Eighteen 18 male turkeys aged 4 weeks were puchased from a turkey breeder in Medan, North Sumatra and maintained in the Laboratory of Experimental Animal of the Faculty of Veterinary Medicine of Universitas Syiah Kuala.

\subsection{Research Methods}

This study used a completely randomized design (CRD). Data on live body weight were recorded at the age of 8,16 , and 24 weeks. Six turkeys were sacrified at each age category for testes collection. The morphology of the testes were visually observed. The weight of testes were measured using a digital scale. Data were analyzed descriptively.

\section{RESULTS AND DISCUSSION}

\subsection{Morphoanatomy}

Turkey's testicles are a pair, oval shaped bean like organs located in the abdominal cavity, dorsal intestines, caudal lungs and ventral kidneys. These findings are in accordance with those reported by Tamilselvan et al. [12] based on their study on guinea fowl. The testes are creamy white in color with black color in some of their parts (Figure 1). Yunanta [13], Deviche et al. [14] and Tamilselvan et al. [12] added that the testes are limited by the mesorchium ligament.

When the livestock reach sexual maturity, both male and female reproductive organs begin to develop so that the reproduction process can take place properly [15]. As the turkey gets older, the size of the reproductive organs also increase [11].

Observation of testicular size can be done by measuring the length, circumference, and weight of the testes [16]. The results of testicular measurements provide an idea of the reproductive potential of a male

animal [17. Anatomically normal testes are testes that have the appropriate length, circumference, and weight. Cells responsible for the anatomy of the testes are spermatogenic cells, Sertoli cells, and Leydig cells [9].

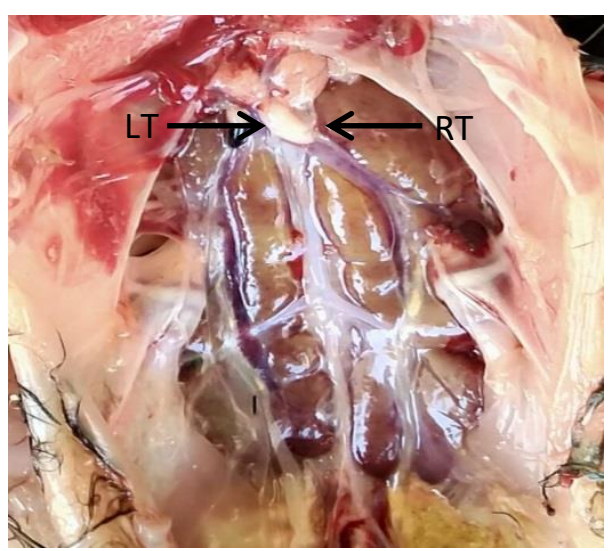

Figure 1 Testes of eight weeks old M. gallopavo. RTright testis, LT-left testis.

\subsubsection{Body Weight}

The average body weight of turkey by age is 8 weeks old $0.89 \pm 0.06 \mathrm{~kg}, 16$ weeks old $1.74 \pm 0.27 \mathrm{~kg}$, and 24 weeks old $3.78 \pm 0.85 \mathrm{~kg}$. Turkey weight increases according to age.

\subsubsection{Testicular Weight}

The average turkey testicular weight by age group were age 8 weeks old $0.08 \pm 0.03 \mathrm{~g}$, age 16 weeks old $0.24 \pm 0.09 \mathrm{~g}$, and age 24 weeks old $3.83 \pm 3.99 \mathrm{~g}$.

\subsubsection{Gonadosomatic Index}

Gonadosomatic index (GSI) represents the percentage of testicular weight divided by weight. As shown in the Table 1 , the GSI of 8,16 , and 24 turkeys were $0.96 \pm 0.32 \%, 1.32 \pm 0.42 \%$, and $9.53 \pm 8.26 \%$, respectively.

Table 1. Gonadosomatic index of turkeys

\begin{tabular}{|l|l|l|l|}
\hline Age (week) & Paired testes weight (gr) & Body weight (gr) & GSI (\%) \\
\hline 8 & $0.09 \pm 0.03$ & $888.33 \pm 60.14$ & $0.96 \pm 0.32^{\mathrm{a}}$ \\
\hline 16 & $0.24 \pm 0.09$ & $1,743.33 \pm 274.20$ & $1.32 \pm 0.42^{\mathrm{a}}$ \\
\hline 24 & $3.83 \pm 3.99$ & $3,783.33 \pm 844.79$ & $9.53 \pm 8.26^{\mathrm{b}}$ \\
\hline
\end{tabular}

${ }^{\mathrm{a}, \mathrm{b}}$ Different superscript in the same column shows a significant difference at $\alpha=0.05$.

According to Dharani et al. [17], the GSI relates to the efficiency of spermatozoa production in males. In this study, it was found that the GSI of the 24-week old turkeys largely increased compared to the previous age groups, 
reflecting that at the age of 24 weeks, sperm reproduction in turkeys was already very efficient.

\section{CONCLUSION}

The GSI of male turkeys increase in line with age which indicating to the development of male reproduction in the animals.

\section{AUTHORS’ CONTRIBUTIONS}

DM, MA, GG, and SW designed, performed, and prepared the manuscript. All authors read and approved the final manuscript.

\section{ACKNOWLEDGMENTS}

The authors gratefully acknowledge the Faculty of Veterinary Medicine, Universitas Syiah Kuala for the facility provided.

\section{REFERENCES}

[1] A. Pohontu, A. Lomboan, J.F. Paath, S.C. Rimbing, Penampilan reproduksi ternak sapi potong di kecamatan Bintauna Kabupaten Bolaang Mongondow Utara. Jurnal Zootek, 38 (2018) 102113.

[2] D. Purwantini, S.A. Santosa, A. Trioko, Perbaikan mutu genetik melalui seleksi induk hasil persilangan itik tegal dengan magelang, Prosiding Seminar Teknologi dan Agribisnis Peternakan V. Purwokerto, 18 November 2017, pp. 289-295.

[3] M.M. Tariq, E. Eyduran, M.A. Bajwa, A. Waheed, F. Iqbal, Y. Javed, Prediction of body weight from testicular and morphological characteristics in indigenous Mengali sheep of Pakistan using factor analysis scores in multiple linear regression analysis. Int. J. Agric. Biol. 14(4) (2012) 590-594.

[4] F.E. Ferianto, I. Setiawan, W. Tanwiriah, Identifikasi sifat-sifat kuantitatif kalkun (Meleagris gallopavo) jantan dan betina dewasa. Jurnal Unpad 4(3) (2015) $1-8$.

[5] M. Lukmanudin, C. Sumantri, S. Darwati, Ukuran tubuh ayam lokal silangan IPB d-1 generasi kelima umur 2 sampai 12 minggu, Jurnal Ilmu Produksi dan Teknologi Hasil Peternakan 6(3) (2018) 113-120.

[6] B. Sarwono, Ragam Ayam Piaraan. Penebar Swadaya. Jakarta, 1994.

[7] S.I.A. Elbajory, M.D.E. Tingari, M.A. Abdalla. Morphological study of the testis of adult Suandese duck (Anas platyrhinchos). Int. J. Anim. Vet. Adv. 5(3) (2013) 103-107.
[8] A. Fitriyah, W. Wihandoyo, S. Supadmo, I. Ismaya. Blood plasma hormone testosterone level and sperm quails (Coturnix coturnix japonica) quality caused by lemuru fish and palm oil. Anim. Prod. 10(3) (2008) 157-163.

[9] W.A. Pradipta, Y.S. Ondho, D. Samsudewa, Anatomi testis tiktok dengan pemberian gel lidah buaya (Aloe vera). Agromedia 32(2) (2014) 24-30.

[10] E. Setiyono, R.P. Bekti, Karakteristik morfologi dan perkembangan testis itik alabio (Anas platyrhynchos Borneo) periode grower. Life Sci. 8(2) (2019) 170180.

[11] C. Rirgiyensi, Y. Sistina, F.N. Rachmawati, Ukuran organ sistem reproduksi itik jantan yang disuplementasi probiotik MEP+ berbagai dosis selama 30 hari. Scripta Biol. 1(3) (2014) 179-184.

[12] S. Tamilselvan, B.S. Dhote, I. Singh, M.S. Mrigesh, S. Sathapathy, D. Mahanta, Gross morphology of testes and gonadosomatic index (GSI) of guinea fowl (Numida meleagris). J. Entomol. Zool. Studies 6(3) (2018) 156-159.

[13] T. Yunanta, Dasar Ternak Unggas. Indonesia, Yogyakarta, Kanisius, 2004.

[14] P. Deviche, L.L. Hurley, H.B. Fokidis, Avian testicular structure, function, and regulation. Hormones and Reproduction of Vertebrates 4 (2011) 27-70.

[15] N. M. A. G. R. Astiti, Sapi Bali dan Pemasarannya. Indonesia, Bali, Warmadewa University Press. 2018.

[16] W. Isnaeni, A. Fitriyah, N. Setiati, Pengaruh pemberian omega-3, omega-6, dan kolesterol sintetis terhadap kualitas reproduksi burung puyuh jantan. Biosaintifika 2(1) (2010) 40-52.

[17] P. Dharani, S. Ushakumary, V. Sundaram, C. Joseph, G. Ramesh, Morphological analysis of testis of the guinea fowl (Numida meleagris) under tropical savannah climate of India. Int. J. Morphol. 36(3) (2018) 909-914 